Artikel Penelitian

\title{
Komparasi Aktivitas Antioksidatif Ekstrak Teh Putih (Camellia sinensis Linn.) Dibandingkan Ekstrak Biji Anggur dan BHA pada Berbagai Konsentrasi
}

\section{Comparison Antioxidant Activity of White Tea (Camellia sinensis Linn.) Extract and Grape Seed Extract plus BHA in Various Concentrations}

Rohadi , Sri Budi Wahjuningsih

Jurusan Teknologi Hasil Pertanian, Universitas Semarang, Semarang

"Korespondensi dengan penulis Rohadi (rohadijarod_ftp@usm.ac.id)

Artikel ini dikirim pada tanggal 26 Februari 2018 dan dinyatakan diterima tanggal 27 Mei 2018. Artikel ini juga dipublikasi secara online melalui www.jatp.ift.or.id. Hak cipta dilindungi undang-undang. Dilarang diperbanyak untuk tujuan komersial.

Diproduksi oleh Indonesian Food Technologists $® ~(2018$

\begin{abstract}
Abstrak
Teh putih merupakan produk olahan teh (Camellia sinensis Linn.) yang spesifik antara lain bahan baku berasal dari pucuk daun teh yang masih menggulung (kuncup), diolah tanpa melalui proses fermentasi dan berwarna putih keperakan. Tujuan penelitian adalah mengukur sifat antioksidatif ekstrak teh putih pada berbagai konsentrasi (25$150 \mathrm{ppm}$ ) dengan pembanding ekstrak biji anggur (EBA) dan antioksidan sintetik butylated hydroxyanisole (BHA). Teh putih diekstraksi dengan metode maserasi (bahan: aquades $=1: 10$; selama 10 menit pada suhu $60 \pm 2^{\circ} \mathrm{C}$ ). Seduhan teh disaring dengan kertas saring Whatman 4, filtrat yang diperoleh dikering bekukan sebagai ekstrak teh putih (ETP) yang kemudian disimpan pada suhu $<-20^{\circ} \mathrm{C}$ untuk dilakukan analisis selanjutnya. Hasil penelitian menunjukan yield ekstraksi teh putih $14,42 \pm 1,66 \%(\mathrm{~b} / \mathrm{b})$, total fenolik dan flavonoid ETP adalah masing-masing

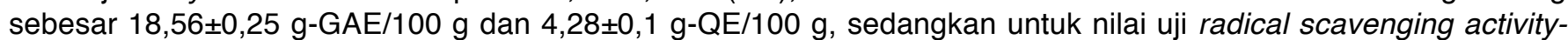
DPPH (RSA-DPPH) ETP adalah 14,15 $\pm 0,10 \%$. Terdapat signifikansi kapasitas penangkapan radikal bebas DPPH antar ekstrak $(25-150 \mathrm{ppm})$ dengan urutan ETP < BHA < EBA $(p<0,05)$. Nilai uji FRAP untuk ETP adalah 0,169 $\pm 0,001(\mathrm{OD})$. Terdapat signifikansi kapasitas mereduksi ion Feri (FRAP) antar ekstrak (25-150 ppm) dengan urutan $\mathrm{ETP}<\mathrm{BHA}<\mathrm{EBA}(p<0,05)$. Dari penelitian ini dapat disimpulkan bahwa total fenolik dan flavonoid ETP dapat ditentukan dengan baik dan jika dibandingkan dengan BHA dan EBA maka ETP dengan pelarut air ini menunjukkan hasil yang lebih kecil dari BHA dan EBA.
\end{abstract}

Kata kunci: Ekstrak teh putih, antioksidan, ekstrak biji anggur, BHA, ekstrak biji anggur

\begin{abstract}
White tea is a product processed specifically from tea leaves (Camellia sinensis Linn.). It is made with the top bud of tea plant. After picking, the leaves are minimally oxidized (unfermented process) and the leaves are easily recognizable as they possess a silver needle. The research was conducted to determine the antioxidant activity of white tea extract (WTE) in various concentration [25-150 ppm]. Comparison with grape seed extract (GSE) and BHA were also conducted. Tea infusion was prepared by placing $50 \mathrm{~g}$ of white tea in $500 \mathrm{ml}$ of distillated water $\left(1: 10 / 60 \pm 2^{\circ} \mathrm{C}\right)$ and steeping for 10 minutes. The sample (tea infusion) was filtered through Whatman filter paper No.4 and the extract were freeze-dried, then the extract stored at $-20^{\circ} \mathrm{C}$ until further analysis. The result showed yield of white tea extraction was $14.42 \pm 1.66 \%(\mathrm{~W} / \mathrm{W})$, the total phenolic and the total flavonoid content of WTE was $18.56 \pm 0.25(\mathrm{~g}-\mathrm{GAE} / 100 \mathrm{~g})$ and $4.28 \pm 0.1(\mathrm{~g}-\mathrm{QE} / 100 \mathrm{~g})$, respectively. Antioxidant activities of WTE (150 ppm) against the $D P P H$ radical were $14.15 \pm 0.10 \%$. There were differences significantly possess radical scavenging activity-DPPH among extract in all concentrations $(25-150 \mathrm{ppm})$ with the order WTE $<B H A<G S E(p<0.05)$. Antioxidant activities of WTE (150 ppm) against the ion Ferric were $0.169 \pm 0.001(O D)$. There were differences significantly possess their reduction activity against the ion Ferric among extract in all concentration (25-150 ppm), with the order WTE $<B H A$ $<$ GSE $(p<0.05)$. As conclusion antioxidant activity of aqueous WTE was successfully detected but wasn't as strong as GSE and BHA.
\end{abstract}

Keywords: White tea extract; antioxidant; grape seed extract; BHA, grape seed extract

\section{Pendahuluan}

Teh putih merupakan produk olahan teh (Camellia sinensis Linn.) yang spesifik antara lain bahan baku berasal dari pucuk daun teh yang menggulung (kuncup), diolah minimal meliputi pelayuan (steaming) dan pengeringan saja tanpa melalui proses fermentasi serta warna seduhannya putih keperakan. Hal ini berbeda dengan proses pembuatan teh hitam atau teh hijau. Menurut Rai et al. (2012) kandungan katekin pada teh putih mencapai $20-30 \%$ dari berat kering, jauh lebih tinggi dibanding teh hijau. Senyawa fenolik yang utama adalah epicatechin (EC), epigallocatechin (EGC), epicatechin-3-gallate (ECG) dan epigallocatechin-3gallate (EGCG) yang merupakan turunan katekin (Hilal dan Engelhardt, 2007). Senyawa flavonol terdiri atas kuersetin, kaemferol dan mirisetin (Hilal dan Engelhardt, 2007; Almajano et al. 2011; Forester dan Lambert, 2011). Metode pengolahan, lokasi tumbuh, jenis pucuk, agroklimat dan varietas berpengaruh terhadap kompoisi 
kimia ekstrak (Hilal dan Engelhardt, 2007; Forester dan Lambert, 2011; Rai et al. 2012).

Tram et al. (2015) mengoptimasi ekstraksi senyawa fenolik teh putih dengan metode assisted microwave time (10-20 detik), rasio teh/air (1:40-1:80), lama waktu ekstraksi (30-50 menit) dan suhu ekstraksi $\left(77-87^{\circ} \mathrm{C}\right)$, hasilnya setara $20,68 \pm 0,37-23,97 \pm 0,35 \%$ (gGAE/100 g-ekstrak).

Widyasanti et al. (2016) melaporkan aktivitas antioksidatif ekstrak teh putih dengan pelarut $n$-heksan $(\varepsilon=2)$, etil asetat $(\varepsilon=6)$ dan etanol $(\varepsilon=24,3)$ berturut-turut sebesar 22,01, 57,54, dan 59,32 g GAE/100 g. Penelitian sifat antioksidan ekstrak teh putih yang dikomparasi dengan antioksidan alami ekstrak biji anggur (grape seed extract -GSE) dan antioksidan sintetik BHA masih terbatas, sehingga publikasi tentang hal ini perlu dilakukan. Penelitian ini bertujuan untuk melakukan pengukuran sifat antioksidatif ekstrak teh putih pada berbagai konsentrasi dengan pembanding ekstrak biji anggur (EBA) dan antioksidan sintetik butylated hydroxyanisole (BHA). Manfaatnya adalah dapat memperoleh informasi mengenai antioksidan dari ekstrak teh putih agar dapat digunakan sebagai referensi lebih jauh untuk proses selanjutnya.

\section{Materi dan Metode \\ Materi}

Materi yang dipakai meliputi teh putih Kaligua, dibeli langsung dari PT. Perkebunan Nusantara IX, asam galat hidrat (Sigma Chemical Co. St. Louis USA), kuersetin (Waco Pure Chemical Industry-Osaka Japan), butylated hydroxyanisole atau BHA (Sigma Chemical Co.), asam hidroklorida $(\mathrm{HCl})$, fero klorida $\left(\mathrm{FeCl}_{2}\right)$, feri khlorida $\left(\mathrm{FeCl}_{3}\right)$, amonium tiosianat, $\mathrm{K}_{3} \mathrm{Fe}(\mathrm{CN})_{6}$, trychloroacetic acid (TCA), 2,2-diphenyl-1-picrylhydracyl radical (DPPH) (Aldrich Chemical Co.), grape seed extract (Bulk Powder, UK), kertas saring Whatman No.4 (Whatman International, Ltd. England), Folin-Ciocalteu reagent dan phosphate buffer $\mathrm{pH}$ 7. Bahan kimia untuk analisis dan standar yang digunakan kategori PA (proanalisis). Peralatan yang dipakai meliputi timbangan analitik Shimadzu AUW 120 (Shimadzu, Kyoto Japan), a rotary vacuum evaporator (IKA-RV 10 Basic, USA), freeze dryer (PowerDry LL 1500 Thermo Scientific, USA), water-bath shaker (Julabo SW 22), UV-Visible spectrophotometer (UV-1601 Shimadzu, Japan).

\section{Analisis Kadar Air Ekstrak Teh Putih}

Sampel yang telah dihaluskan, sebanyak 2 gram dimasukkan ke dalam botol timbang (telah dikeringkan dalam oven pada suhu $105^{\circ} \mathrm{C}$ dan diketahui berat konstan). Sampel (dalam botol) dikeringkan pada suhu $105^{\circ} \mathrm{C}$ selama $5 \mathrm{jam}$, lalu didinginkan dalam desikator, kemudian ditimbang. Sampel dipanaskan lagi dalam oven selama 30 menit, kemudian didinginkan dan ditimbang. Perlakuan ini diulang sampai tercapai berat konstan. Pengurangan berat sampel merupakan banyaknya air dalam sampel. Rasio pengurangan berat terhadap berat sampel mula-mula dikalikan $100 \%$ dinyatakan sebagai kadar air (\%) (Latimer, 2005).

\section{Analisis Protein Ekstrak Teh Putih}

Sampel (2 g) dimasukkan ke dalam labu Kjeldhal, ditambahkan 2 buah tablet katalisator $\mathrm{K}_{2} \mathrm{SO}_{4}$ atau $\mathrm{CuSO}_{4}, 5$ butir batu didih, $15 \mathrm{ml} \mathrm{H}_{2} \mathrm{SO}_{4}$ pekat serta $3 \mathrm{ml}$ $\mathrm{H}_{2} \mathrm{O}_{2} 30 \%$. Selanjutnya dipanaskan pada alat destruksi di dalam lemari asam dengan suhu $450^{\circ} \mathrm{C}$ selama 2 jam sampai cairan contoh bening. Hasil destruksi, ditambahkan $100 \mathrm{ml}$ aquades ke dalam hasil destruksi, kemudian dipasangkan labu tersebut pada alat destilasi. Setelah itu, dilakukan penakaran sebanyak $25 \mathrm{ml} \mathrm{H}_{3} \mathrm{BO}_{4}$ dan dimasukkan ke labu erlenmeyer $250 \mathrm{ml}$ serta ditambahkan 2 tetes indikator Methylene Blue lalu, sehingga diperoleh distilat. Distilat yang diperoleh, dititrasi dengan larutan $\mathrm{HCl}$ standar $0,2 \mathrm{~N}$ hingga titik akhir titrasi berakhir (ditandai oleh perubahan warna kuring menjadi merah muda (pink). Kadar protein (\%) dihitung sebagai hasil kali selisih volume titrasi sampelblangko dengan normalitas $\mathrm{HCl}$, dengan berat molekul nitrogen kali faktor konversi dibagi dengan berat sampel kali 100 persen (Latimer, 2005):

\section{Analisis Lemak Ekstrak Teh Putih}

Sampel ( $2 \mathrm{~g})$ dibungkus dengan kertas saring lalu dimasukkan pada selubung sampel (labu lemak). Proses selanjutnya adalah penambahan $150 \mathrm{ml}$ kloroform ke dalam labu lemak yang kemudian dipasangkan pada ekstraktor, kemudian dilanjutkan dengan pemasangan botol sampel ke dalam labu Soxhlet (terendam pelarutnya). Sampel direfluks pada suhu $60^{\circ} \mathrm{C}$ selama 8 jam. Ekstrak yang didapatkan kemudian dihilangkan sisa pelarutnya dengan dengan rotary evaporator, yang dilanjutkan dengan pengovenan labu sampel (berisi ekstrak) ke dalam oven suhu $105^{\circ} \mathrm{C}$ untuk proses penghilangan sisa pelarutnya yang dilakukan selama \pm 1 jam. Selanjutnya, ekstrak didinginkan dalam eksikator selama 30 menit. Kadar lemak (\%) dihitung sebagai rasio berat ekstrak dengan berat sampel dikalikan 100 persen (Latimer, 2005).

\section{Analisis Abu Ekstrak Teh Putih}

Sampel (2 g) dimasukkan pada cawan porselen (diketahui berat konstan) dan dipijarkan dalam furnace pada suhu $550^{\circ} \mathrm{C}$ hingga diperoleh sisa pembakaran (abu) yang berwarna putih keperakan. Cawan yang berisi abu sampel dikeluarkan dengan cepat dan dimasukkan pada desikator. Rasio berat sebelum dan setelah dihitung untuk mendapatkan kadar abu (Latimer, 2005).

\section{Analisis Serat Kasar Ekstrak Teh Putih}

Sampel $(2 \mathrm{~g})$ lolos ayakan dengan $\varnothing 1 \mathrm{~mm}$, dimasukkan pada labu erlenmeyer $600 \mathrm{ml}$, lalu ditambahkan senyawa anti buih dan $200 \mathrm{ml} \mathrm{H}_{2} \mathrm{SO}_{4}$ mendidih, yang kemudian ditutup. Proses pemanasan selanjutnya dilakukan hingga mendidih selama 30 menit sambil digoyang. Suspensi ini lalu disaring dengan kertas saring, residu yang ada pada erlenmeyer dicuci dengan air mendidih sampai bersih. Residu dalam kertas saring dicuci sampai air cucian tidak bersifat asam (dilihat dengan indikator kertas lakmus). Residu pada kertas saring dipindahkan ke labu erlenmeyer dengan 
spatula. Sisanya dicuci dengan $200 \mathrm{ml}$ larutan $\mathrm{NaOH}$ mendidih sampai semua residu masuk pada labu erlenmeyer. Selanjutnya, dilakukan pemanasan hingga mendidih dengan perangkat pendingin balik sambil digoyang selama 30 menit. Proses selanjutnya adalah penyaringan dengan kertas saring (yang sudah diketahui beratnya) sambil dicuci dengan larutan $\mathrm{K}_{2} \mathrm{SO}_{4} \quad 10 \%$ (yang dicuci ulang dengan air mendidih dan dengan alkohol 15 sebanyak $\mathrm{ml}$ ). Kertas saring kemudian dikeringkan pada suhu $110^{\circ} \mathrm{C}$ hingga dicapai berat konstan (sekitar 2 jam). Kertas kemudian didinginkan dalam desikator dan ditimbang.

\section{Metode Ekstraksi Teh Putih}

Cara melakukan ekstraksi teh putih "Kaligua" dilaksanakan sesuai metode peneliti sebelumnya (Vasi dan Austin, 2009) dengan modifikasi. Sebanyak $50 \mathrm{~g}$ sampel diekstrak dengan $500 \mathrm{ml}$ aquades (1:10) (10 menit $/ 60 \pm 2^{\circ} \mathrm{C}$ ) dengan teknik maserasi. Campuran difiltrasi dengan kertas saring Whatman, sehingga diperoleh ekstrak. Ekstraksi diulangi 2 kali dengan metode dan pelarut yang sama. Ekstrak yang diperoleh dipekatkan dengan rotary vacuum evaporator (IKA-RV 10 Basic, USA) dan diperoleh cairan kental. Selanjutnya cairan kental dikering-bekukan dengan freeze dryer (PowerDry LL 1500 Thermo Scientific, USA). Sisa pelarut dihilangkan dengan penyemprotan gas nitrogen $\left(\mathrm{N}_{2}\right)$, sehingga diperoleh ekstrak bubuk, kemudian dihitung hasilnya (yield).

\section{Uji Total Fenolik}

Uji total fenolik dikerjakan dengan reagen FolinCiocalteu menurut peneliti sebelumnya (Ebrahimzadeh et al., 2008). Sebanyak dengan 0,5 mg ETP dilarutkan dalam $1 \mathrm{ml}$ metanol dan ditambahkan 0,5 reagen Folin Ciocalteu (1:1) dicampur hingga homogen, lalu dibiarkan selama 8 menit. Pada campuran ditambahkan $4,5 \mathrm{ml}$ $\mathrm{Na}_{2} \mathrm{CO}_{3} 2 \%$, disimpan di ruang gelap (suhu kamar selama 60 menit), selanjutnya diukur absorbansinya (UV-1601 Shimadzu, Japan) pada $\lambda=765 \mathrm{~nm}$. Nilai OD diplotkan pada persamaan regresi kurva standar asam galat, sehingga dapat diketahui konsentrasi total fenolik (mg-GAE/g-ETP).

\section{Uji Aktivitas Antioksidan Total Flavonoid}

Uji aktivitas antioksidan total flavonoid dikerjakan menurut (Ebrahimzadeh et al. 2008). Sebanyak 0,5 mg ETP dilarutkan dalam $1,5 \mathrm{ml}$ metanol dan ditambahkan $0,1 \mathrm{ml}$ aluminium chloride $10 \%, 0,1 \mathrm{ml}$ potasium acetat $1 \mathrm{M}$ dan 2,8 $\mathrm{ml}$ aquades dan dihomogenkan. Campuran disimpan pada suhu ruang selama 30 menit, selanjutnya ditera absorbansi/OD (UV-1601 Shimadzu, Japan) pada $\lambda=415 \mathrm{~nm}$. Nilai OD diplotkan pada persamaan regresi linier kurva standar kuersetin, sehingga dapat dihitung total flavonoid (mg-QE/g).

\section{Uji Penangkapan Radikal Bebas DPPH (RSA-DPPH)}

Uji penangkapan radikal bebas DPPH (radical scavenging activity-DPPH) dilakukan menurut Vasi dan Austin, (2009). Larutan $0,5 \mathrm{ml}$ ETP dari beragam konsentrasi $(25,50,75,100,125$, dan 150 ppm) digunakan sebagai sampel. Sampel kemudian ditambah pada $0,5 \mathrm{ml}$ larutan DPPH $(100 \mu \mathrm{M})$ dalam metanol, lalu didiamkan pada suhu ruang $\left(37 \pm 2^{\circ} \mathrm{C}\right)$. Setelah 15 menit, ditera nilai absorbansinya pada $\lambda=517 \mathrm{~nm}$. Antioksidan BHA dan GSE digunakan sebagai pembanding dan kontrol (tanpa ekstrak). Eksperimen dilakukan sebanyak tiga kali ulangan. Aktivitas penangkapan radikal bebas DPPH dapat dihitung dengan persamaan Vasi dan Austin (2009), yaitu satu dikurangi dengan pembagian nilai absorbansi sampel dan nilai absorbansi control yang kemudian dikalikan seratus persen.

\section{Uji Aktivitas Antioksidan Mereduksi ion Feri $\left(\mathrm{Fe}^{3+}\right)$}

Uji aktivitas antioksidan mereduksi ion feri (ferric reducing antioxidant power -FRAP) dikerjakan menurut Vasi dan Austin, (2009). Sampel sebanyak 2,5 ml larutan ETP, GSE dan BHA dari beragam konsentrasi $(25,50$, $75,100,125$ dan $150 \mathrm{ppm}$ ), dicampur dengan $2,5 \mathrm{ml}$ buffer phosphate $(0,2 \mathrm{M} / \mathrm{pH} 6,6)$ dan $2,5 \mathrm{ml}$ potassium ferricyanide $\left(\mathrm{K}_{3} \mathrm{Fe}(\mathrm{CN})_{6} \quad 1 \%\right.$. Campuran tersebut diinkubasi pada suhu $50^{\circ} \mathrm{C}$ selama 20 menit. Selanjutnya ditambahkan 2,5 ml trichloroacetic acid (TCA) 10\% untuk menghentikan reaksi dan disentrifugasi pada $3.000 \mathrm{rpm}$ selama 10 menit. Lapisan bagian atas sebanyak $2,5 \mathrm{ml}$ dicampur dengan aquades $(2,5 \mathrm{ml})$ dan $0,5 \mathrm{ml} \mathrm{FeCl}_{3}$ $0,1 \%$ dan ditera absorbansinya masing-masing sampel dengan spektrofotometer pada $\lambda=700 \mathrm{~nm}$. Peningkatan absorbansi/OD sebagai indikator peningkatan daya mereduksi.

\section{Analisis Statistik}

Data yang diperoleh disajikan dalam format ratarata \pm sd dan dianalisis dengan metode One-Way ANOVA yang diperoleh dengan menggunakan SPSS 23.0 dengan level signifikansi $a=0,05$.

\section{Hasil dan Pembahasan}

Sampel yang digunakan adalah "Teh Putih Kaligua" sebanyak 250 gram yang dibeli langsung dari pabrik teh yang berlokasi di Kaligua dalam keadaan baik. Kondisi teh kering berkadar air 7,44 $\pm 0,064 \%$, dinilai cukup mengkilap dan warna kuning-putih susu, hasil pengukuran warna $\left(\mathrm{L}^{*} \mathrm{a}^{*} \mathrm{~b}^{*}\right)$ masing-masing sebesar $44,59 \pm 0,06 ; 3,34 \pm 0,01 ; 7,54 \pm 0,06$. Hasil analisis komposisi kimia tersaji pada Tabel 1.

\begin{tabular}{lc}
\multicolumn{2}{c}{ Tabel 1. Hasil analisis kimia ekstrak teh putih } \\
\hline \multicolumn{1}{c}{ Komponen kimia } & Hasil Analisis (\%) \\
\hline Air & $7,44 \pm 0,064$ \\
Abu & $5,39 \pm 0,133$ \\
Lipid & $0,32 \pm 0,008$ \\
Protein & $28,63 \pm 0,17$ \\
Serat kasar & $12,10 \pm 0,076$ \\
Komponen lain & $46,04 \pm 0,054$ \\
\hline
\end{tabular}

\section{Hasil (yield) Ekstraksi}

Hasil (yield) ekstraksi Teh Putih Kaligua dengan pelarut air berupa ekstrak bubuk berwarna merah coklat sebesar $14,42 \pm 1,66 \%$. Nilai rendemen ekstraksi teh putih dengan pelarut $\mathrm{n}$-heksan, etil asetat dan etanol $96 \%$ berturut-turut $0,62 \pm 0,04 \%, \quad 1,82 \pm 0,27 \%$ dan $9,42 \pm 1,88 \%$ (Widyasanti et al. 2016). Perbedaan nilai 
rendemen tersebut disebabkan antara lain oleh perbedaan jenis dan polaritas pelarut, serta metode ekstraksi (Martin et al. 2011; Tram et al. 2015).

\section{Total Fenolik Ekstrak Teh Putih}

Kuantitas senyawa fenolik suatu ekstrak tanaman atau hewan dapat diestimasi antara lain melalui analisis total fenolik dan total flavonoid (Prior et al., 2005; Dai and Mumper et al., 2010; Rydlewski et al., 2013). Hasil analisis total fenolik ETP diperoleh hasil sebesar $18,56 \pm 0,25 \%$ (g-GAE/100 g dry-extract), dengan referensi dari persamaan regresi kurva standar asam galat $y=0,143 x-0,18 ; R^{2}=0,987$. Tram et al. (2015) melaporkan ekstraksi senyawa fenolik teh putih dengan metode assisted microwave time (10-20 detik), rasio teh/air (1:40-1:80), waktu ekstraksi (30-50 menit) dan suhu $\left(77-87^{\circ} \mathrm{C}\right)$, dan menunjukkan hasil yang tidak jauh berbeda, yakni 20,68 $\pm 0,37-23,97 \pm 0,35 \%$ (g-GAE/100 gdry-extract). Nilai total fenolik suatu ekstrak secara signifikan bergantung kepada jenis dan polaritas pelarut, rasio bahan dengan pelarut, suhu, metode, serta lama ekstraksi (Martin et al., 2011; Tram et al., 2015). Widyasanti et al. (2016) mengatakan total fenolik ETP dengan pelarut $n$-heksan $(\varepsilon=2)$, etil asetat $(\varepsilon=6)$ dan etanol $(\varepsilon=24,3)$ berturut-turut adalah $22,01,57,54$, dan $59,32 \%$. Air $(\varepsilon=80,2)$ sebagai pelarut polar mampu mengekstrak senyawa polar dari zat warna, zat pembentuk citarasa, dan tanin.

\section{Total Flavonoid Ekstrak Teh Putih}

Hasil analisis total flavonoid ETP sebesar $4,28 \pm 0,1 \%$ (g-QE/100 g dry-extract) dengan referensi regresi kurva standar kuersetin (quercetin) $\mathrm{y}=1,365 \mathrm{x}+$ 0,$007 ; R^{2}=0,996$. Sedangkan Hilal dan Engelhardt, (2007) menyebut nilai total flavonoid ETP dengan pelarut metanol $70 \%$ sebesar $13,22 \%$ (g-catechin/100 g dryextract). Nilai total flavonoid sampel selalu lebih rendah dibanding total fenoliknya, hal ini karena senyawa flavonoid dengan struktur bangun spesifik C6-C3-C6 merupakan bagian dari kelompok fenolik dengan ciri khusus struktur fenol (Heim et al. 2002). Perbedaan nilai total flavonoid ETP disebabkan perbedaan jenis dan polaritas pelarut, rasio bahan - pelarut, frekuensi, suhu, lama serta metode ekstraksi (Martin et al., 2011). Nilai total fenolik dan flavonoid korelatif dengan aktivitas antioksidan penangkapan radikal bebas DPPH dan kemampuan mereduksi ion Feri $\left(\mathrm{Fe}^{3+}\right)$ ekstrak (Widyasanti et al., 2015; Hajiaghaalipour et al., 2015; dan Rohadi et al., 2016).

Aktivitas Penangkapan Radikal Bebas DPPH (RSADPPH)

Salah satu sifat antioksidan adalah kemampuannya menangkap radikal bebas (Brewer, 2011). Hasil uji penangkapan radikal bebas pada konsentrasi 25-150 ppm menunjukkan bahwa ETP memiliki kemampuan menangkap radikal bebas DPPH yang lemah pada kisaran 5,31 $\pm 0,14-14,15 \pm 0,1 \%$ $\left(\mathrm{IC}_{50}=641 \mathrm{ug} / \mathrm{ml}\right)$ dan hasil ini lebih rendah bila dibandingkan dengan GSE dan BHA. Terdapat perbedaan signifikan aktivitas penangkapan radikal bebas DPPH antara ETP, GSE dan BHA $(p<0,05)$ (Tabel 2). Dilaporkan oleh Hajiaghaalipour et al. (2015), nilai $I_{50}$ ekstrak teh putih $\left(100^{\circ} \mathrm{C}\right.$ selama 5 menit) adalah 99,9 ug/ml, sementara ETP dengan menggunakan n-heksan, etil asetat dan etanol $96 \%$ dilaporkan mempunyai nilai $I_{50}$ berturut-turut sebesar 203,78, 11,207, dan 5,153 ug/ml (Widyasanti et al. 2015).

Perbedaan aktivitas penangkapan radikal bebas DPPH antar ekstrak diduga disebabkan antara lain adanya perbedaan kuantitas dan ragam senyawa fenolik ekstrak. Dilaporkan Hilal dan Engelhardt (2007), teh putih mengandung senyawa fenolik antara lain total catechin sebesar $13,22 \%$, epigallocatechine gallat sebanyak $8 \%$, epigallocatechin sebesar $1,11 \%$, caffeine sebesar $4,84 \%$, flavonol glikosida sebesar $1,25 \%$ dan flavonol aglikon sebesar $0,61 \%$ (semuanya dalam satuan g/100 g). Pada ekstrak biji anggur (GSE) diketahui mengandung $95 \%$ senyawa kelompok oligomeric proanthocianidin (Bulkpowder, 2015). Proantosianidin merupakan polifenolik yang banyak gugus ${ }^{-} \mathrm{OH}$ (donor atom hidrogen) yang mampu melakukan aksi quenching $\cdot \mathrm{O}^{-}$dan mengkelat ion logam (Shahidi dan Wanasundara, 1992). Sedangkan BHA senyawa fenolik sintetik yang banyak mengandung gugus hidroksil (Botterweck et al. 1999).

Tabel 2. Hasil analisis RSA-DPPH ekstrak teh putih (\%)

\begin{tabular}{cccc}
\hline $\begin{array}{c}\text { Konsentrasi } \\
(\mathrm{ppm})\end{array}$ & \multicolumn{3}{c}{ Macam Sampel } \\
\cline { 2 - 4 } & ETP & ETP & BHA \\
\hline 25 & $5,31 \pm 0,14^{\mathrm{a}}$ & $13,28 \pm 0,1^{\mathrm{b}}$ & $14,53 \pm 0,28^{\mathrm{c}}$ \\
50 & $6,49 \pm 0,1^{\mathrm{a}}$ & $14,18 \pm 0,1^{\mathrm{b}}$ & $15,38 \pm 0,1^{\mathrm{c}}$ \\
75 & $7,66 \pm 0,14^{\mathrm{a}}$ & $17,08 \pm 0,1^{\mathrm{b}}$ & $16,58 \pm 0,1^{\mathrm{c}}$ \\
100 & $9,24 \pm 0,1^{\mathrm{a}}$ & $24,50 \pm 0,1^{\mathrm{b}}$ & $17,79 \pm 0,1^{\mathrm{c}}$ \\
125 & $11,18 \pm 0,1^{\mathrm{a}}$ & $26,9 \pm 0,1^{\mathrm{b}}$ & $21,29 \pm 0,1^{\mathrm{c}}$ \\
150 & $14,15 \pm 0,1^{\mathrm{a}}$ & $33,42 \pm 0,1^{\mathrm{b}}$ & $24,30 \pm 0,1^{\mathrm{c}}$ \\
\hline
\end{tabular}

Keterangan: ETP $=$ ekstrak teh putih, GSE $=$ grape seed extract, $\mathrm{BHA}=$ butylatedhydroxy anysol. Huruf superskrip yang sama pada baris yang sama menunjukkan tidak ada beda nyata antar perlakuan $(p<$ $0,05), n=2$.

Tabel 3. Hasil Analisis Aktivitas Mereduksi ion $\mathrm{Fe}^{3+}$ (OD) Konsentrasi Macam Sampel

\begin{tabular}{cccc}
$(\mathrm{ppm})$ & $\mathrm{ETP}$ & $\mathrm{EBA}$ & $\mathrm{BHA}$ \\
\cline { 2 - 4 } 25 & $0,045 \pm 0,001^{\mathrm{a}}$ & $0,089 \pm 0,001^{\mathrm{b}}$ & $0,079 \pm 0,001^{\mathrm{c}}$ \\
50 & $0,07 \pm 0,001^{\mathrm{a}}$ & $0,15 \pm 0,001^{\mathrm{b}}$ & $0,106 \pm 0,001^{\mathrm{c}}$ \\
75 & $0,101 \pm 0,001^{\mathrm{a}}$ & $0,18 \pm 0,001^{\mathrm{b}}$ & $0,13 \pm 0,001^{\mathrm{c}}$ \\
100 & $0,124 \pm 0,001^{\mathrm{a}}$ & $0,215 \pm 0,001^{\mathrm{b}}$ & $0,156 \pm 0,001^{\mathrm{c}}$ \\
125 & $0,146 \pm 0,001^{\mathrm{a}}$ & $0,251 \pm 0,001^{\mathrm{b}}$ & $0,185 \pm 0,001^{\mathrm{c}}$ \\
150 & $0,169 \pm 0,001^{\mathrm{a}}$ & $0,295 \pm 0,001^{\mathrm{b}}$ & $0,221 \pm 0,001^{\mathrm{c}}$
\end{tabular}

Keterangan ETP = ekstrak teh putih, EBA $=$ ekstrak biji anggur, $\mathrm{BH}=$ =butylated hydroxyanysol. Huruf superskrip yang sama pada baris yang sama menunjukkan tidak ada beda nyata antar perlakuan $(p<0,05), \mathrm{n}=2$.

\section{Aktivitas mereduksi ion Feri (FRAP)}

Salah satu sifat zat/senyawa sebagai antioksidan adalah kemampuannya mereduksi ion Feri $\left(\mathrm{Fe}^{3+}\right)$ (Durackova, 2008; Brewer, 2011). Hasil uji FRAP sampel menunjukkan bahwa ETP memiliki kemampuan mereduksi yang lemah $(O D=0,045-0,169)$ bila dibandingkan dengan GSE dan BHA serta terdapat perbedaan signifikan dalam aktivitas mereduksi ion Feri antara ETP, GSE dan BHA $(p<0,05)$ (Tabel 3). 
Kemampuan mereduksi ion Feri $\left(\mathrm{Fe}^{3+}\right)$ menjadi ion Fero $\left(\mathrm{Fe}^{2+}\right)$ oleh senyawa organik bersifat korelatif dengan kapasitas antioksidannya (Jayaprakasha et al., 2001). Semakin besar nilai optical density (OD) sebuah sampel, maka semakin besar pula kemampuan mereduksinya (Vasi dan Austin, 2009). Perbedaan kemampuan mereduksi ion Feri $\left(\mathrm{Fe}^{3+}\right)$ antar ekstrak diduga disebabkan antara lain adanya perbedaan kuantitas dan ragam senyawa fenolik pada ekstrak (Hilal dan Engelhardt, 2007). Rohadi et al. (2017) mengatakan sifat antioksidatif yang kuat pada ekstrak metanolik biji duwet pada uji RSA DPPH dan FRAP disebabkan oleh kandungan senyawa tanin dan katekhin yang melimpah.

\section{Kesimpulan}

Hasil ekstraksi teh putih didapatkan sebesar 14,42 $\pm 1,66 \%$, ekstrak teh putih yang dihasilkan memiliki total fenolik dan flavonoid masing-masing sebesar $18,56 \pm 0,25$ dan $4,28 \pm 0,1 \%$ (g-QE/100 g-ekstrak). Aktivitas antioksidan ekstrak teh putih pada penangkapan radikal bebas DPPH semakin meningkat seiring dengan peningkatan konsentrasi, namun tidak sekuat BHA dan EBA. Kemampuan mereduksi ion Feri pada ekstrak teh putih, dinilai semakin meningkat seiring dengan peningkatan konsentrasi, namun tidak sekuat $\mathrm{BHA}$ dan EBA.

\section{Ucapan Terima kasih}

Pada kesempatan ini penulis mengucapkan terimakasih kepada Lembaga Penelitan dan Pengabdian Masyarakat (LPPM) Universitas Semarang yang telah membantu pendanaan untuk penelitian ini dengan kontrak: No. 298/USM.H9/L/2017. Ucapan terimakasih juga disampaikan kepada Ahmad Syahri Romadhon, Diyan Widyantika, serta Fonda Natalia yang telah membantu dalam penelitian ini.

\section{Daftar Pustaka}

Almajano, M.P., Villa, I., Gines, S. 2011. Neuroprotective effects of white tea against oxidative stress-induced toxicty in striatal cells. Neurotoxicity Research 20: 372-378. DOI:10.1038/ sj.bjp. 0706255.

Brewer, M.S. 2011. Natural Antioxidant: Source, Compounds, Mechanisms of Action, and Potential Application. Comprehensive Reviews. Food Science and Food Safety 10: 221-247.

Botterweck, A.A.M., Verhagen, H., Goldbohm, R.A., Kleinjans, J., van Den Brant, P.A. 1999. Intake of butylated hydroxyanisole and butylated hydroxytoluene and stomach cancer risk: Results from analyses in the Netherland cohort study. Food and Chemical Toxicology 38:599-605.

Bulkpowders. 2015. Grape seed extract contains a minimum 95\% OPC. Retrieved on May 12, 2015 from bulkpowders. Website: http://www.bulkpowders.co.uk/grape-seedextract.html. [diakses tanggal 12 Mei 2015].

Dai, J. dan Mumper, R.J. 2010. Plant Phenolic: Extraction, Analysis and Their antioxidant and
Anticancer Properties (Review). Molecules 15:7313-7352. DOI:10.3390/molecules15107313.

Durackova, Z. 2008. Oxidants, antioxidants and oxidative stress. Dalam: Anna Gvozdjakova (Ed.) Mitochondrial medicine: Mitocondrial metabolisme, diseases, diagnosis and therapy. Springer-Verlag New York, LLC.

Ebrahimzadeh, M.A., Pourmorad, F., Hafezi, S. 2008. Antioxidant activities of Iranian corn silk. Turk Journal Biology 32: 43-49.

Forester, S.C, Lambert, J.D. 2011. The role of antioksidant versus prooxidant effect of green tea polyphenols in cancer prevention. Molecular Nutrition and Food Research 55 (6): 844-854.

Heim, K.E., Tagliaferro, A.R., Bobilya, D.J. 2002. Flavonoid antioxidants: chemistry, metabolism and structure-activity relationships. Review. Journal of Nutritional Biochemistry 13: 572-584.

Hilal, Y., Engelhardt, U. 2007. Characterisation of white tea-Comparison to green and black tea. Journal für Verbraucherschutz und Lebensmittelsicherheit 2:414-421. DOI: 10.1007/s00003-007-0250-3.

Jayaprakasha, G.K., Singh, R.P., Sakariah, K.K. 2001. Antioxidant activity of grape seed (Vitis vinifera) extracts on peroxidation models in vitro. Food Chemistry 73: 285-290. DOI: 10.1016/S03088146(00)00298-3.

Latimer, G.W, Jr. 2005. AOAC official methods of analysis. $18^{\text {th }}$ ed. Maryland: AOAC International.

Martin, S., Solange I. Mussatto, G., Martinez-Avila, J., Montanes-Saenz, C.N. Aguilar, Teixeira, J.A. 2011. Bioactive phenolic compounds: Production and extraction by solid-state fermentation. A review. Journal Biotechnology Advances 29:365373. DOI:10.1016/j.biotechadv.2011.01.008

Prior, R.L., Wu, X., Schaich, K. 2005. Standardized methods for the determination of antioxidant capacity and phenolics in foods and dietary supplements (Review). Journal of Agricultural and Food Chemistry 53(10): 4290-4302. DOI:10.1021/jf0502698.

Rai, N., Jigisha, A., Navin, K., Pankaj, G. 2012. Green tea $A$ magical herb with miraculous outmes. International Research Journal of Pharmacy 3(5): 139-148.

Rohadi, Santoso, U., Raharjo, S., Falah, I.I. 2017. Determination of antioxidant activity and phenolic compounds of methanolic extract of Java plum (Syzygium cumini Linn.) (Skeel) Seed. Indonesian Food and Nutrition Progress (IFNP) Vol. 13(1): 920.

Rohadi, Raharjo, S, Falah, I.I., Santoso, U. 2016. Aktivitas antioksidan ekstrak biji Duwet (Syzygium cumini Linn.) pada peroksidasi lipida secara in vitro. Jurnal Agritech 36(1): 30-37. DOI: 10.22146/agritech.10681.

Rydlewski, A.A., de Morais, D.R., Rotta, E.M., Visentainer, J.V. 2013. Evaluation of antioxidant activity of methanolic extract of seed, peel, and pulp of Jambolan (Syzygium cumini). Agricultural 
Science Center of State University of Marings, Colombo.

Shahidi, F., Janitha, P.K., Wanasundara, P.D. 1992. Phenolic antioxidants. Critical Review. Food Science Nutrition, 32(1): 67-103. DOI: 10.1080/10408399209527581

Tram, N.N., Hien, P.P., Oanh, H.N. 2015. Optimizing the extraction conditions of phenolic compounds from fresh tea shoot. Journal of Food and Nutrition Sciences 3(1-2): 106-110. DOI: 10.11648/j.jns.s.2015030102.30.
Vasi, S., Austin, A. 2009. Antioxidants potential of Eugenia jambolana Lam. Seeds. Journal of Biological Sciences 9(8): 894-898. DOI: 10.3923/jbs.2009.894.898.

Widyasanti, A., Rohdiana, D., Ekatama, N. 2016. Aktivitas antioksidan ekstrak teh putih (Camellia sinensis) dengan metode DPPH (2,2 diphenyl, 1picrylhydracil). Fortech 1 (1):1-9.

Widyasanti, A., Marpaung, D.S.S., Nurjanah, S. 2016. Aktivitas antijamur ekstrak teh Putih (Camellia sinensis) terhadap jamur Candida albicans. Jurnal Teknotan 10(2):7-15. 